\title{
High flows from Gornja Dobra basin
}

The Mining-Geology-Petroleum Engineering Bulletin UDC: 556.5

DOI: $10.17794 / \operatorname{rgn} .2018 .3 \cdot 5$

Professional paper

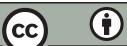

Krešimir Pavlić'; Daniel Jakobović ${ }^{2}$

${ }^{1}$ University of Zagreb, Faculty of Mining, Geology and Petroleum Engineering, Pierottijeva 6, p.p. 390, 10000 Zagreb

${ }^{2}$ HIS d.o.o. Donja Višnjica 61D, 42255 Donja Višnjica

\begin{abstract}
This paper presents basic hydrological indicators based on data from the four existing hydrological stations in the Gornja Dobra basin. The frequency and flow-duration curves of mean daily flow in the Turkovići profile are also defined and presented. The dependence of the mean maximum annual specific flows on the size of the influential basin to the considered hydrological profiles was considered. A review of the most recent high water event in 2017 was given.
\end{abstract}

\section{Keywords}

Gornja Dobra, frequency and flow-duration curve, maximum specific flow, stage-discharge curve, big water wave.

\section{Introduction}

The Dobra River can be divided into three characteristic areas of flow. The first, known as the Gornja (Upper) or Ogulinska Dobra, is $51.2 \mathrm{~km}$ long, stretches from the spring on the north-eastern slopes of the Mlada Gora through Skrad, Kupjak and Ravna Gora settlements to the town of Ogulin where the river sinks into Đulin ponor. From the Đulin ponor, the underground stream continues through the natural system of karstic canals and caverns, about 16,400 $\mathrm{m}$ in length, and on the surface, it flows to the village of Gojak and thus forms the second part of the Dobra River. The Đulin ponor represents a natural drainage system for the high waters of the Upper Dobra and its tributaries. The height difference between the highest and lowest point is $83 \mathrm{~m}$ (Čepelak, 1985). The third part of this watercourse, which flows into the river Kupa, takes on the characteristics of the lowland watercourse called Donja Dobra. Downstream of the hydroelectric power plant Gojak, the hydroelectric power plant Lešće was built on Donja Dobra.

The Dobra River is among the subterranean rivers of Europe and is an important tributary of the Kupa River. Since the Dobra basin is a part of the Dinaric karst, it is characterized by a complex geological structure and shows great variation in hydrological and hydrogeological properties. Consequently, it can be said that karstic aquifers represent heterogeneous systems which are difficult to define due to the constant interaction between surface and groundwater.

Corresponding author: Krešimir Pavlić

e-mail address: kresimir.pavlic@rgn.hr
The main objective of this paper is to determine the dependence of mean maximum annual specific discharge $\bar{q}_{M}$ on the size of the influential basin, to define the frequency and flow-duration curves of mean daily flows and to analyse the most recent flood event that occurred in Ogulin in September 2017. The analysis was carried out on the basis of data collected over 31 years from the period (1981 - 2011), based on the data of the mean and maximum annual flows from hydrological stations in Gornja Dobra and Vitunjčica.

\section{Research area and previous studies of research area}

Most of the current research, except for the Gojak hydroelectric power plant, is based on finding appropriate solutions for the protection of Ogulin, which is endangered by the emergence of high waters. Based on this, a brief overview of the flood in 1999 in Ogulin is presented, the problem of the limited capacity of the Đulin ponor, which is directly related to this issue and the influence of the Gojak hydroelectric power plant on the whole river system is discussed. The importance of solving the problem of flooding the city Ogulin was confirmed by the latest flood in September 2017.

The Dobra River is a karstic river that runs partly as a surface and partly as an underground river. On its way, it passes through karstic conduits of different dimensions (caves and other underground karstic forms), which can be either free water face or under pressure (Prelovšek et al., 2008). Thus, on certain watercourse lines, the Dobra River, depending on the hydrogeological situation, simultaneously loses part of the water in the karst subterranean, but is also fed with water from the karst aquifers. 


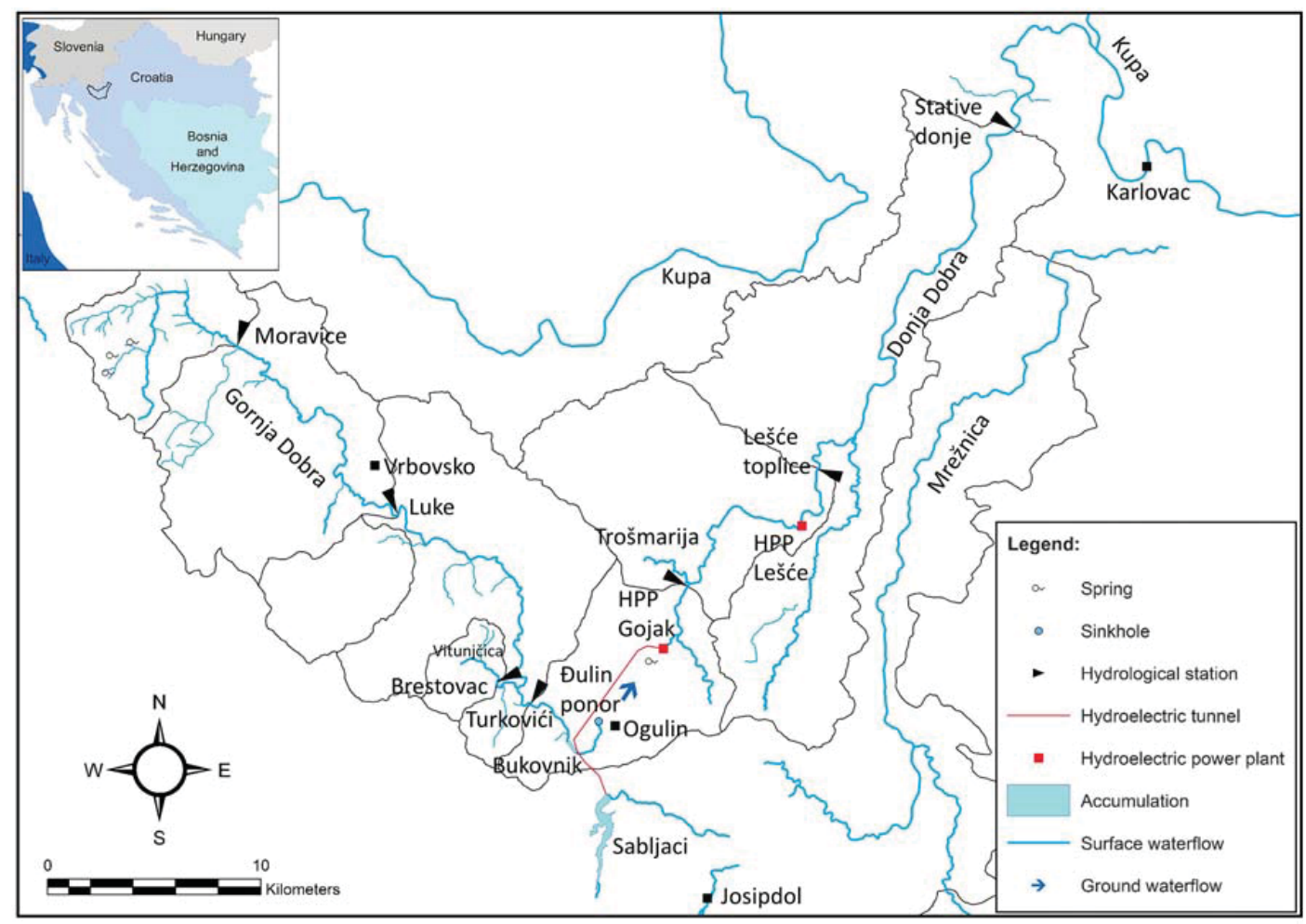

Figure 1: The situation where the river Dobra is marked with Đulin ponor, HPP Gojak, accumulation of Bukovnik and Sabljaki, the positions of all hydrological stations and river catchment

Mean daily flow rates data used in this analysis are taken from the Meteorological and Hydrological Service of the Republic of Croatia (DHMZ) and collected from hydrological stations Moravice, Luke and Turkovići on Gornja (Ogulinska) Dobra and Brestovac stations on Vitunjčica, an important tributary of Gornja Dobra. Vitunjčica flows in Gornja Dobra after $4 \mathrm{~km}$ of flow near the Turkovići village. Figure 1 shows the characteristic parts of the river Dobra, the river catchment, the mentioned hydrological stations, Đulin ponor and the hydroelectric power plant Gojak.

In the hydrogeological sense, the Dobra River basin is a transitional area connecting the Dinaric and Pannonian areas, where three distinct units can also be distinguished. Gornja Dobra begins as a surface runoff with clastics of Paleozoic age in the area of Skrad, and it retains such characteristics to Vrbovsko. Significant karst springs are formed in in the area of Vrbovsko where permeable and impermeable deposits intersect, (IGH, 2009). The watercourse continues on the terrain that is made of limestone and dolomite of Jurassic age. While flowing through the dolomites, no loss of water occurs, but upon contact with limestone, there are sinkholes, as is the case with Đulin ponor. At the intersection of the Triassic clastites and carbonate deposits, the Zagorska Mrežnica River, which, as well as the Gornja Dobra, sinks upon contact between dolomites and limestones. The last part of the Dobra watercourse is Donja
(Gojačka) Dobra, whose flow mostly depends on the operation of the hydroelectric power plant Gojak (Opala and Ožanić, 2010).

Some recent hydrological surveys covered by the Dobra River basin were carried out by Žugaj et al. (19982007), R. Biondić (2005), D. Biondić (2005), Pavlić (2016) and Pavlić et al. (2017), but geological research of the wider area of the karst of Croatia has been conducted by Sudar et al. (2016) and Velić et al. (2017).

Since the town of Ogulin is located in the central part of the river Dobra, there is a great influence of Đulin ponor (see Figure 2), which represents the natural drainage system of high waters. It is noted that flow through the underground system, after the entrance of water into the sinkhole, primarily depends on the underlying condition that is difficult to define. The capacity of Đulin ponor during the flood in 1999 was evaluated: $Q_{\text {d } p}=72.0$ $\mathrm{m}^{3} / \mathrm{s}$ (Brkić, 2001). Due to this limited capacity, a very large water wave cannot completely drain from this area. The Gojak hydroelectric power plant with the Sabljaki and Bukovnik accumulation system plays an important role in the defence against floods.

For the purpose of flood protection, Croatian Waters (the legal entity for water management in Croatia) are planning to build a retention in Ogulin on the upstream part of the basin. The retention will result in a reduction of peak flow of high waters and the retention of floating objects, which by entering the Đulin ponor would reduce 


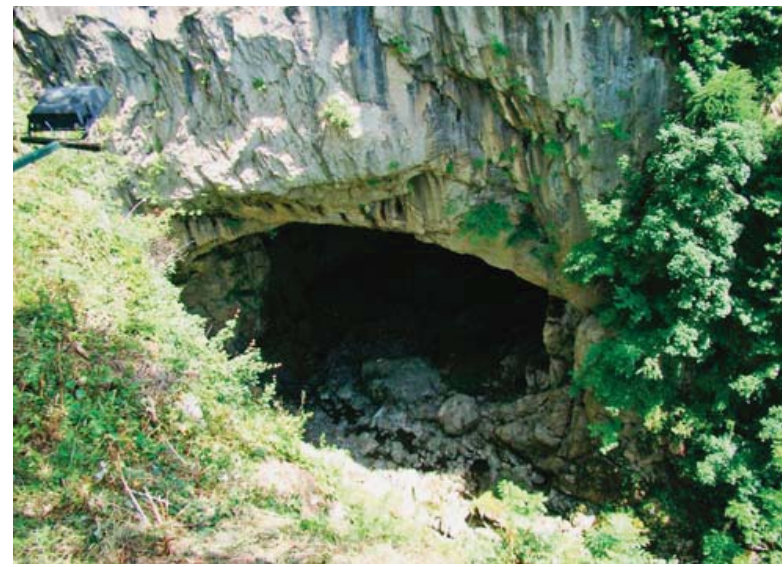

Figure 2: Đulin ponor the flow of the sinkhole. This will ensure the appropriate degree of protection for the city of Ogulin.

The most downstream hydrological profile of Turkovići on Gornja Dobra is located upstream from Ogulin and the small reservoir lake Bukovnik. Data collected at the Turkovići profile is the most important hydrological data for this work. An interesting fact is the size of the basin of the Gornja Dobra, influential to the Turkovići profile, which was earlier $A_{T}=296 \mathrm{~km}^{2}$, and according to recent research $A_{T}=357 \mathrm{~km}^{2}$ (Žugaj et al., 1998-2007), which compared to the earlier value is $20.6 \%$ larger. Since it is a karst area and it is difficult to determine the surface area of the river basin, these sizes should be considered approximate (Žugaj and Pavlić, 2013). Furthermore, it is important to say that the Turkovići profile has a discharge into inundation area of high waters from the river bed (see

$$
\begin{aligned}
& \text { DOBRA - TURKOVIĆI } \\
& \text { HYDROLOGICAL STATION PROFILE } \\
& \text { SCALE } 1: 1000 / 100
\end{aligned}
$$

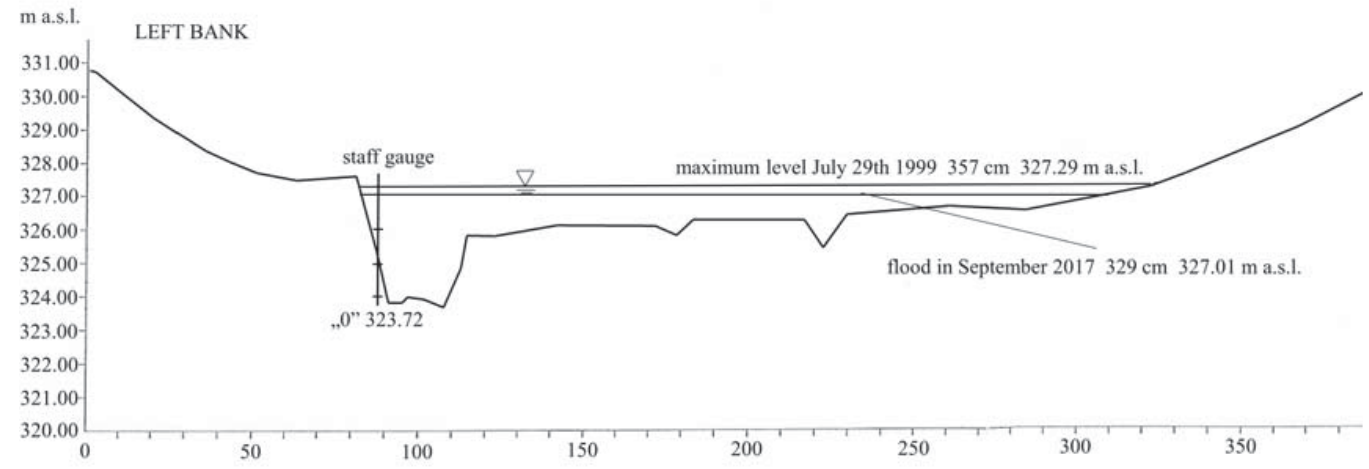

Figure 3: Turkovići hydrological profile (modified after VPB (2001))

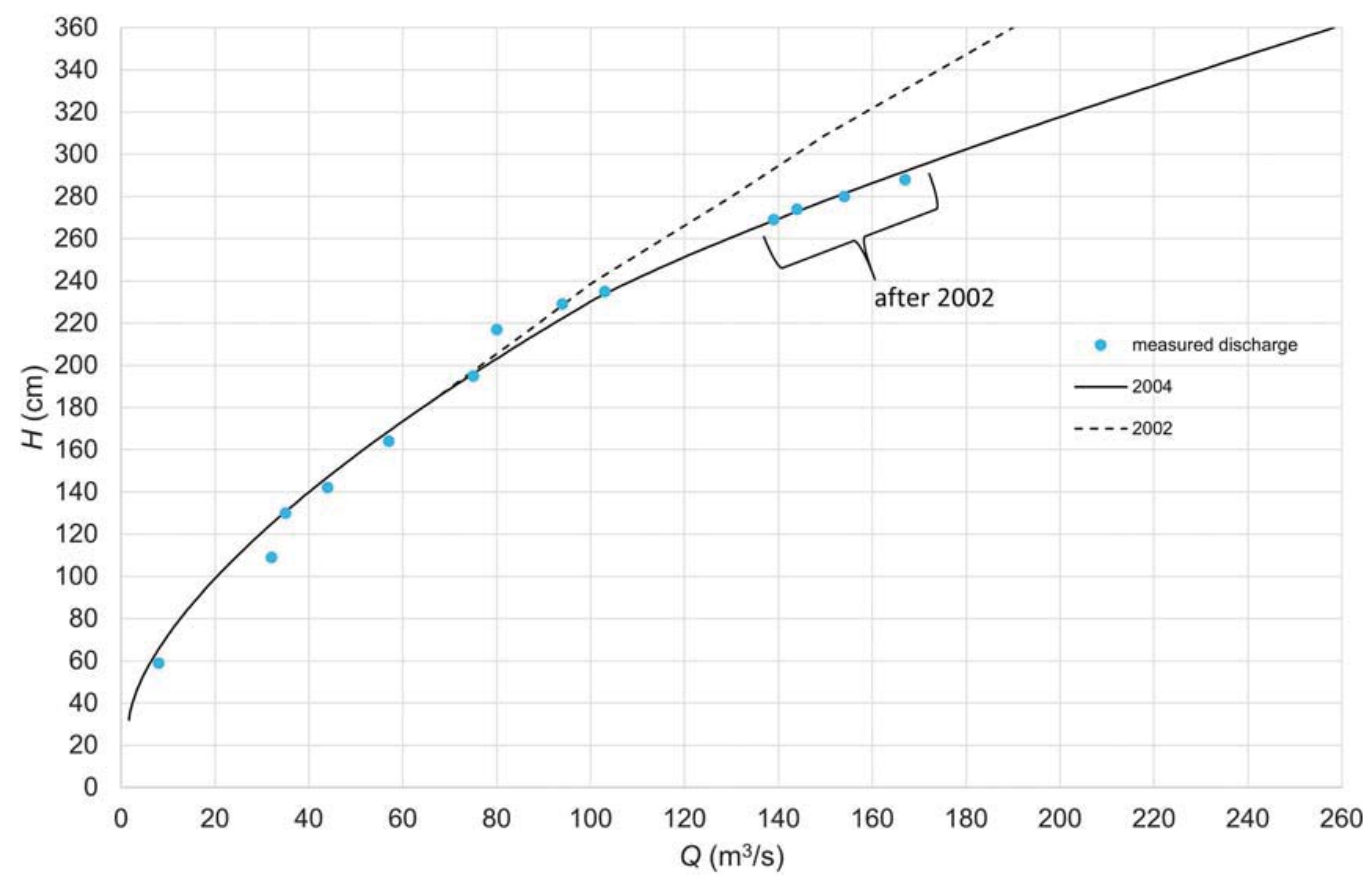

Figure 4: Stage-discharge curves from 2002 and 2004 at Turkovići hydrological profile (VPB, 2005) 
Figure 3). Figure 3 shows the water stage of maximum level recorded in July $29^{\text {th }} 1999$ and the water stage of the most recent flood event in September 2017, which was $327.01 \mathrm{~m}$ a.s.1.

The stage-discharge curve for the Turkovići profile from 2004, which is in use today (see Figure 4), is considered the most reliable due to additional river flow measurements in the high water area after the great flood in Ogulin in 1999.

It was found that the longitudinal slopes of the watercourse are such that there is no damming action because there are several smaller cascades along the river. Thus, the damming will not act on the stage-discharge curve and can be uniquely determined. The fourth or final profile of this analysis is Brestovac on Vitunjčica, an important tributary of Gornja Dobra, whose influence is covered by the Turkovići hydrological station.

\section{Results and discussion}

A statistical analysis of maximum annual flows and volumes of isolated water waves is shown in Figures 5

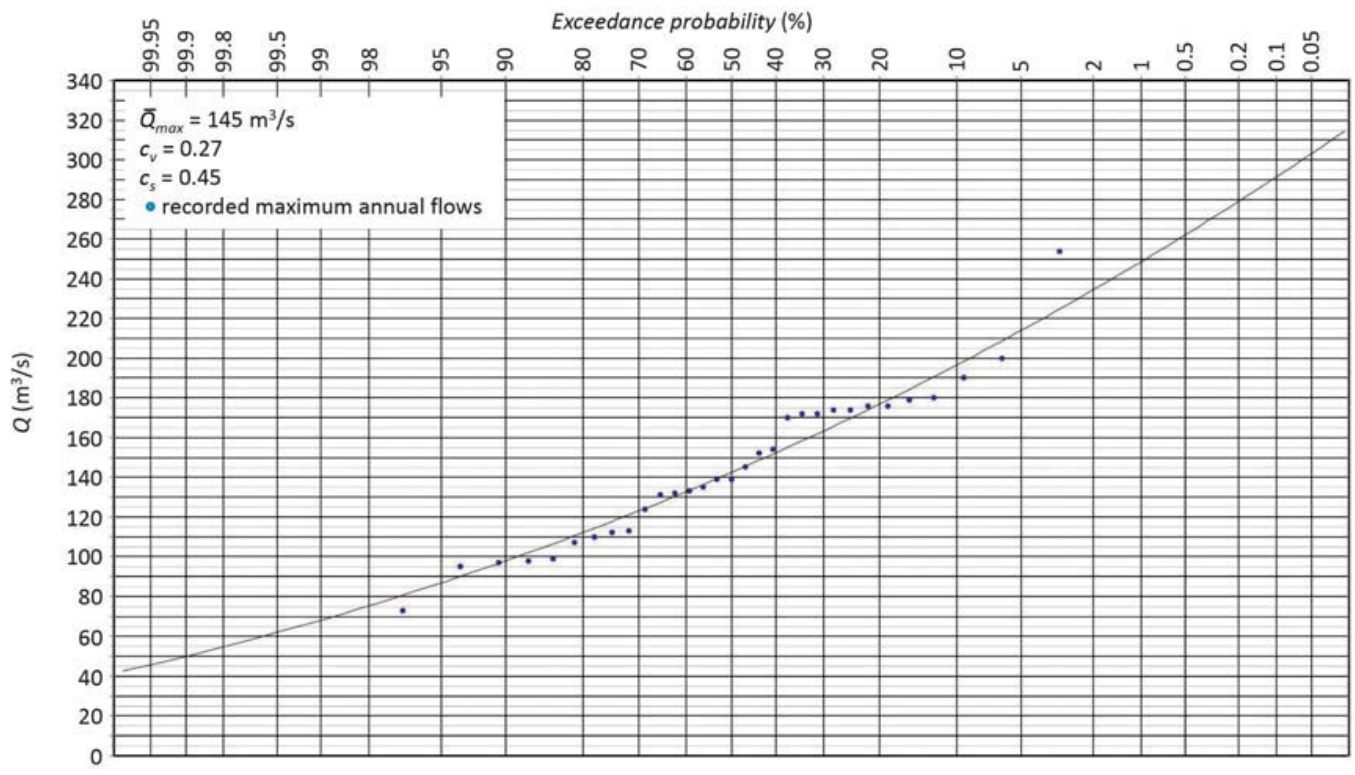

Figure 5: Exceedance probability of maximum annual flows according to Pearson 3 distribution at Turkovići hydrological profile

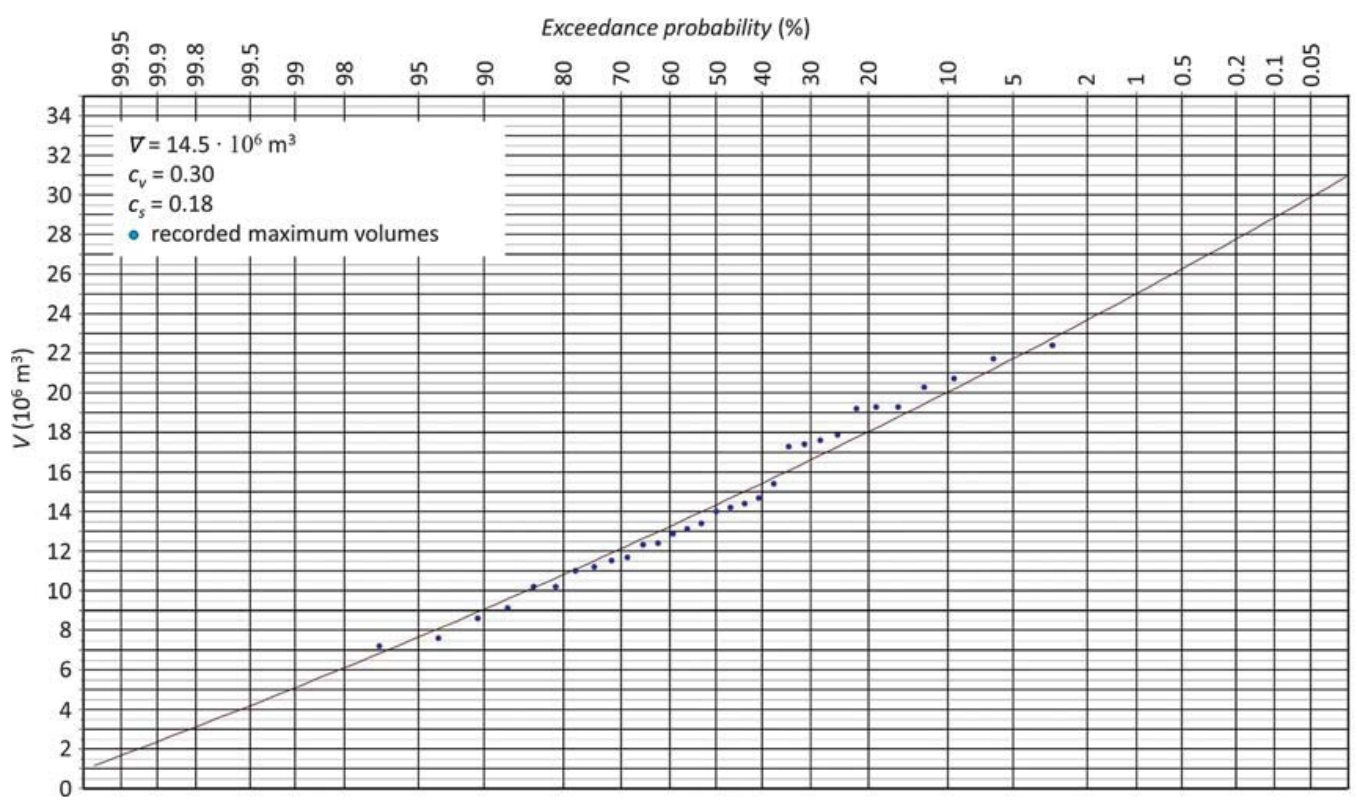

Figure 6: Exceedance probability of maximum volumes of water waves according to Pearson 3 distribution at Turkovići hydrological profile 


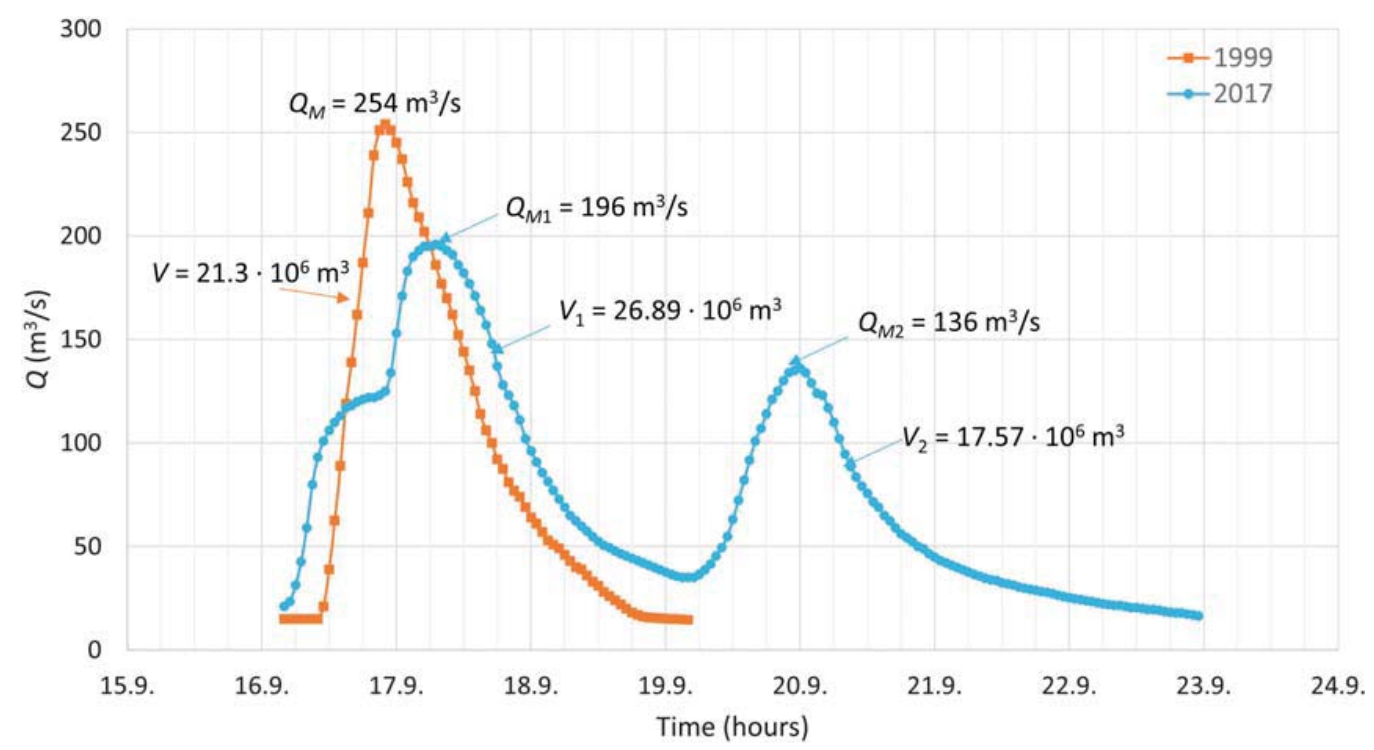

Figure 7: Double water wave recorded at hydrological station Turkovići that occurred in September 2017 together with water wave from July 1999 as a comparison. Plotted values of discharge are hourly values.

and 6. The selected relevant distribution for maximum flows and volumes of large water waves is Pearson 3.

The maximum flow from the 1999 flood, which was $254 \mathrm{~m}^{3} / \mathrm{s}$, had a little bit more than 100-year return period, according to Žugaj and Pavlić (2013). The volume of that water wave was $21.3 \cdot 10^{6} \mathrm{~m}^{3}$, which was about a 20 -year return period. Figure 7 shows the double water wave that occurred in September 2017 together with the water wave that occurred in July 1999, as a comparison.

The first water wave in 2017 had a maximum flow $Q_{M 1}=196 \mathrm{~m}^{3} / \mathrm{s}$ and volume $V_{1}=26.89 \cdot 10^{6} \mathrm{~m}^{3}$. The maximum flow is a 10 -year return period, while its volume is more than a 100-year return period. The second water wave in 2017 had a maximum flow $Q_{M 2}=136 \mathrm{~m}^{3} / \mathrm{s}$ and volume $V_{2}=17.57 \cdot 10^{6} \mathrm{~m}^{3}$. The maximum flow of the second water wave is less than a 2-year return period and its volume is little less than a 5-year return period.

In the first water wave, the return periods did not coincide with flow and volume, while in the second water wave they approximately coincided. Regardless of the fact that the maximum flow and volume of the second water wave was of a smaller return period, it represented a danger because the first water wave saturated the ground with water, which made it possible to create a major flood. Double water waves on the Gornja Dobra basin can cause major flooding, and in particular, attention should be paid to them since they have appeared 11 times since 1963.

It is clear that high waters, in the form of single or double water waves occur regularly on Gornja Dobra, which is a threat to the town of Ogulin. For the purpose of protecting the city of Ogulin from floods, the plan is to build a dam in Turkovići. This dam should flatten the water wave that comes to Ogulin, but the question is whether the dam and the associated retention will be able to capture the entire volume of high water waves, since the area for predicted accumulation is limited by the railway line along the Gornja Dobra, and the fishponds on the left bank of Vitunjčica tributary (IGH, 2013). This suggests that an alternative solution to this problem should be considered, such as the retention of water upstream.

The dependence of mean maximum annual specific discharge $\bar{q}_{M}$ on the size of the catchment area $A$ is derived using data from three hydrological stations: Moravice and Turkovići at Gornja Dobra and Brestovac at Vitunjčica. Data from the profile Luke at Gornja Dobra was not used because value at that station was unrealistically high with respect to derived dependency, as shown in Figure 8. The value of mean maximum annual flow at profile Turkovići is $\bar{Q}_{M}=124 \mathrm{~m}^{3} / \mathrm{s}$, which is quite a high value.

The hydrological profile Luke on the Gornja Dobra is unstable in the hydrological sense, and the stage-discharge curve is extrapolated in a wide range of high waters. When defining the stage-discharge curve in the Turkovići profile, river flow measurements of the 5 and 7 -year return periods were used, and the profile in the hydrological sense was considerably more stable than the Luke profile.

Figure 9 shows frequency and flow-duration curves defined on the basis of daily mean flows in the Turkovići profile. The frequency curve shows an asymmetric shape with a high peak where flows ranging from $2.50 \mathrm{~m}^{3} / \mathrm{s}$ to $7.50 \mathrm{~m}^{3} / \mathrm{s}$ occur more than $35 \%$ of the time during a year. From the flow-duration curve it can be concluded that the mean flows of Gornja Dobra at the Turkovići profile $\left(Q=10.5 \mathrm{~m}^{3} / \mathrm{s}\right)$ and higher, last for $30 \%$ of the total time 


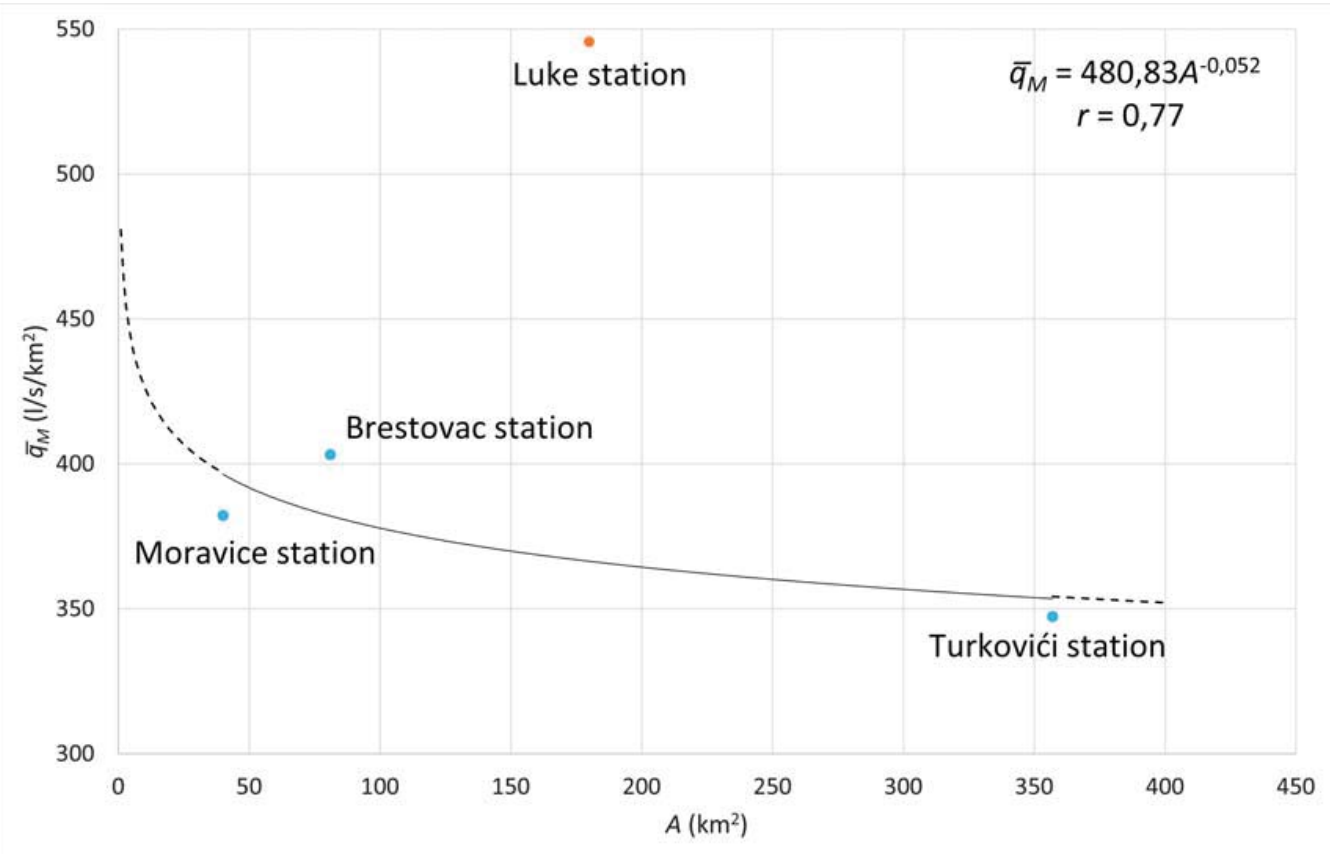

Figure 8: The dependence of mean maximum annual specific discharge $\bar{q}_{M}$ on the size of the catchment area $A$ on Gornja Dobra. Data from Luke hydrological station was not used for deriving the relationship.

\section{Frequency Curve}

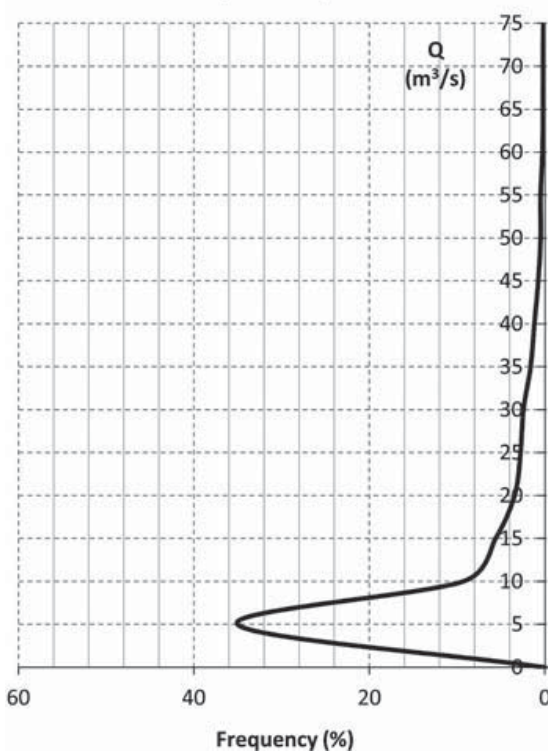

Flow-duration Curve

Figure 9: Frequency and flow-duration curves of mean daily flows of Gornja Dobra in Turkovići profile (1981 - 2011) (Jakobović, 2014) during a year, while the flows lower than the mean flows last for $70 \%$ of the total time during a year. Therefore, the main feature of the flow-duration curve has quite a favourable distribution for energy use.

Frequency and flow-duration curves for values of flow greater than $75.0 \mathrm{~m}^{3} / \mathrm{s}$ show very low frequencies and short durations of such flow rates.

\section{Conclusion}

The Dobra River represents a karst phenomenon characterized by a great changeability of hydrological and hydrogeological features of the catchment area. By part of its flow, it flows as a surface, and partly as a subterranean stream, which makes it into the most famous waterways of that type. 
The appearance of high waters on the Gornja Dobra basin is especially dangerous in the case of double water waves. From 1963 to the present day, 11 double high water waves appeared. Therefore, the solution for the protection of the city of Ogulin from floods should take particular account of the occurrence of such water waves and consider the possibility of retention of water upstream from Turkovići.

The specific mean maximum discharges $\overline{q_{M}}$ on the Moravice profile show lower values than those assumed, which is explained by water losses in the underground. The hydrometric profile of Luke, in which the flow values of high waters are estimated on the basis of an unreliable stage-discharge curve, shows large deviations and data from that station were not used for defining the dependence of mean maximum annual specific discharge $\bar{q}_{M}$ on the size of catchment area $A$. The specific mean maximum discharges $\bar{q}_{M}$ on the Turkovići profile show assumed values, so the stage-discharge curve that is now used in the high waters is adequate.

Gornja Dobra shows a favourable flow distribution in the Turkovici profile. Mean flow and flow rates higher than mean last $30 \%$ of the total time while flows lower than mean last $70 \%$ of the time, which is a good distribution for energy generation use.

\section{References}

Biondić, D. (2005): Velike vode hrvatskih vodotoka crnomorskog sliva (High waters of Croatian watercourses of the Black Sea basin). University of Zagreb, Faculty of Civil Engineering, $\mathrm{PhD}$ Thesis. (in Croatian)

Biondić, R. (2005): Zaštita voda gornjega dijela sliva Kupe (Protection of the water from the upper part of the Kupa basin). University of Zagreb, Faculty of Mining, Geology and Peroleum Engineering, $\mathrm{PhD}$ Thesis. (in Croatian)

Brkić, B. (2001): Zaštita grada Ogulina od velikih voda, idejno rješenje (Protection of city Ogulin from high waters, a conceptual solution). Zagreb: Vodoprivredno-projektni biro (VPB) d.d., Hidrološke obrade, knjiga 1. (in Croatian)

Čepelak, M. (1985): Špiljski sustav Đula-Medvedica (ĐulaMedvedica cave system). Speleolog, 2-24. (in Croatian)

HIDROINŽENJERING d.o.o. (2015): Retencija Ogulin s pripadajućim građevinama - Elaborat zaštite okoliša ( $\mathrm{Ogu}$ lin retention with related buildings - Environmental Elaboration), Zagreb. (in Croatian)

Institut IGH d.d. (2009): Plan navodnjavanja Karlovačke županije (Irrigation Plan of Karlovac County). IGH Projekt, Zavod za hidrotehničko projektiranje, Zagreb. (in Croatian)
Institut IGH d.d. (2013): Retencija Ogulin s pripadajućim građevinama (Ogulin retention with related buildings). IGH Projekt, Zavod za geotehniku, Zagreb. (in Croatian)

Jakobović, D. (2014): Karakteristični protoci sa sliva Gornje Dobre (Characteristic flows from Gornja Dobra basin). University of Zagreb, Faculty of Mining, Geology and Peroleum Engineering, Bachelor's Thesis. (in Croatian)

Opala, I. and Ožanić, N. (2010): Hidrološka analiza sliva rijeke Dobre (Hydrological Analysis of Dobra River Catchment Area), Zbornik radova, knjiga VIII, Građevinski fakultet Sveučilišta u Rijeci, Rijeka, 11-33. (in Croatian)

Prelovšek, M., Turk, J. and Gabrovšek, F. (2008): Hydrodynamic aspect of caves. International Journal of Speleology, 37 (1), 11-26.

Pavlić, K. (2016): Regionalna Hidrološka analiza krškog poriječja Kupe (Regional Hydrological Analysis of the Kupa Karstic Basin). University of Zagreb, Faculty of Mining, Geology and Peroleum Engineering, PhD Thesis. (in Croatian)

Pavlić, K., Kovač, Z. and Jurlina, T. (2017): Trend analysis of mean and high flows in response to climate warming-Evidence from karstic catchments in Croatia. Geofizika, 34 (1), 157-174.

Sudar, V., Aljinović, D., Smirčić, D. and Barudžija, U. (2016): Composition and provenance of Gröden sandstone from the Velebit Mts. The Mining-Geology-Petroleum Engineering Bulletin, 31 (1), 53-67.

Velić, J., Velić, I., Kljajo, D., Protrka, K., Škrabić, H. and Špoljar, Z. (2017): An geological overview of glacial accumulation and erosional occurrences at the Velebit and the Biokovo Mts., Croatia. The Mining-Geology-Petroleum Engineering Bulletin, 32 (4), 77-96.

VPB (2001): Zaštita grada Ogulina od velikih voda: Knjiga 1 - Hidrološke obrade (Protecting the City of Ogulin from the High Waters: Book 1 - Hydrological Processing). Zagreb. (in Croatian)

VPB (2005): Stručna podloga za izradu studije o utjecaju na okoliš retencije Ogulin: hidrološko-hidraulički proračun (Expertise for the Study on Environmental Impact Assessment of Ogulin: Hydrological and Hydraulic Processing). Zagreb. (in Croatian)

Žugaj, R., Andreić, Ž., Pavlić, K. and Fuštar, L. (2011): Krivulje trajanja protoka (Flow duration curves). Građevinar, 63 (12), 1061-1068. (in Croatian)

Žugaj, R. and Pavlić, K. (2013): Peer Review of Preliminary Project "Ogulin Retention in Turkovići" in Terms of the Acceptability of Adopted Hydrological Data and Analyses with Implementation of Additional Hydrological Analyses of Gornja Dobra High Waters. (in Croatian)

Žugaj, R., Jurak, V., Plantić, K., Galović, I., Košćal, S. (19982007): Regionalna analiza slivova Kupe i pritoka u Kršu, Znanstveni projekt MZOŠ, RGNF, Zagreb. (in Croatian) 


\section{SAŽETAK}

\section{Velike vode na slijevu Gornje Dobre}

U radu su na osnovi podataka s četiriju postojećih hidroloških stanica na slijevu Gornje Dobre razmatrani osnovni hidrološki pokazatelji. Definirane su i grafički prikazane krivulja učestalosti i krivulja trajanja srednjih dnevnih protoka u profilu Turkovići. Razmatrana je zakonitost veze maksimalnih srednjih godišnjih specifičnih dotoka u ovisnosti o veličini slijevova te o razmatranim hidrološkim profilima. Razmatrani su veliki vodni valovi iz 1999. i 2017. godine.

\section{Ključne riječi:}

Gornja Dobra, krivulja učestalosti i trajanja, maksimalni specifični dotoci, protočna krivulja, veliki vodni val

\section{Authors contributions:}

Krešimir Pavlic (Dsc.) carried out a statistical analysis and analysed the most recent major water wave. Daniel Jakobović gave an overview of the current research and research area and analysed the historical data. 